\title{
202 ディーゼル機関の低温始動時における未蛞炭化水素の排出特性
}

Emission Characteristics of Unburned Hydrocarbon from Diesel Engine During Cold-Starting

$\begin{array}{rll}\text { ○学 } & \text { 川端 } & \text { 大貴（北見工大院） } \\ \text { 正 } & \text { 石谷 } & \text { 博美（北見工大） } \\ & \text { 山田 } & \text { 広行（いす心゙） }\end{array}$

Daiki KAWABATA, Kitami Institute of Technology, 165Koen-cho, Kitami, Hokkaido

Kota YAMADA, Aishin AI

Hiromi ISHITANI, Kitami Institute of Technology

Kazuhiro HAYASHIDA, Kitami Institute of Technology

Hiroyuki YAMADA, Isuzu Motors

Hiraku KASHIWAGURA, Isuzu Motors

Key Words: Diesel Engine, Cold-Starting, Unburned Hydrocarbon, Exhaust Emission

1. はじめに

ディーゼル機関の低温始動時は, 圧縮端温度が低いことや, 燃料微粒化の悪化などから,クランキング期間が長期化する. クランキング中には多くの燃料が噴射されるため, 始動直後 には燃焼に寄与しなかった未燃燃料, 燃料の熱分解や部分酸 化などにより生成された HC 成分が多く排出される. HC は 低温始動時に排出される青・白煙や排気臭気の主な原因成分 とされており 1), 始動時の HC 排出の低減が求められている. 常温始動時に排出される炭化水素に関しては知見がある 2) が, 低温始動時に排出される具体的な HC 成分やその挙動に ついては不明な点が多い.

そこで本研究では, 低温始動時における排出ガス中の HC 成分のうち, 特に然料の熱分解成分である低級炭化水素の濃 度について詳細に調べる. また低級炭化水素の部分酸化で生 成される CO 濃度も合わせて調べる.

\section{2. 実験装置および方法}

実験装置の概略図を図 1 に示す.供試機関はボア $95.4 \mathrm{~mm}$, ストローク $104.9 \mathrm{~mm}$, 行程容積 $3 \mathrm{~L}$, 圧縮比 17.5 のコモンレ ール式水冷直列 4 気筒 DI ディーゼル機関である. エンジン の ECU は PC と慗がっており，燃料噴射量や噴射タイミン グを変更することができる. 使用燃料はセタン価 51.9 の JIS 特 3 号軽油である.

エンジンは低温室内に設置されており, エンジンのソーク 温度をー30〜 $0{ }^{\circ} \mathrm{C}$ の任意の温度に設定することができる. エ ンジン始動条件を統一するため, エンジンオイルが所定の温 度に達してから 10 時間のソークを行った後に実験を開始す る. そして, 実験終了後は後処理装置を再生し, 後処理装置 内に残った HC 成分の焼却を行う。

低級炭化水素は, 排気ガスをサンプリングバッグに採取し， ガスクロマトグラフ（島津製作所 GC-14B）で分析を行う。 また, $\mathrm{HC}, \mathrm{CO}$ 濃度は非分散赤外線吸収法による $\mathrm{HC} ・ \mathrm{CO}$ アナライザ (HORIBA MEXA-321) を用いて計測する.なお, 排気ガスのサンプリングは後処理装置前後で行い, HC 成分 が凝縮しないようサンプリングラインを $200^{\circ} \mathrm{C}$ に保温する.

\section{3. 実験結果および考察}

図 2 に低温始動時のクランキング開始から始動に到るま での回転数と燃料噴射量の変化を示す.エンジン回転数は始 動初期に $850 \mathrm{rpm}$ になるよう設定されており, 目標回転数に
なるよう噴射量が調整されている. 燃料噴射はプレとメイン の 2 回噴射で行われており, 図に示す噴射量はプレとメイン の合計值である.図より，ソーク温度が低くなるほどクラン キング時間が延び，燃料噴射量も増加している事が分かる. これは圧縮端温度が低いことや, 燃料噴霧の微粒化の悪化, およびエンジンオイルの粘性が高くなり摩擦トルクが大き くなることなどが原因と言える.

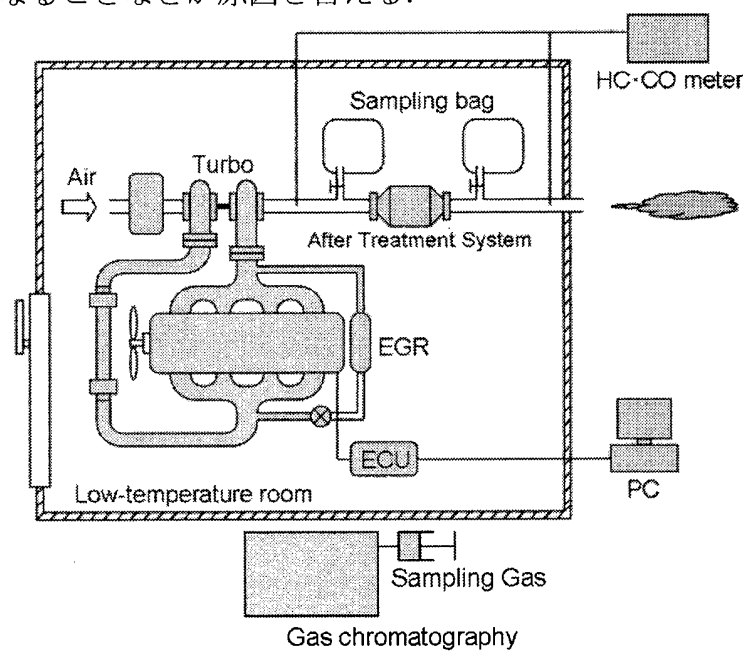

Fig.1 Experimental apparatus

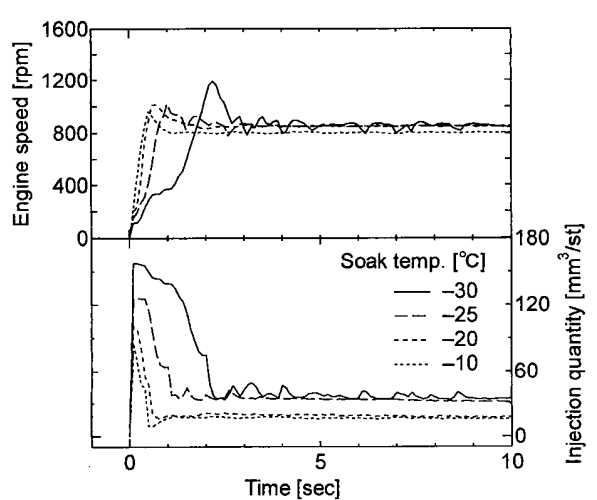

Fig.2 Engine speed and injection quantity 


\section{3-1 HC 濃度}

図 3 に各ソーク温度の後処理装置前における HC 濃度の時 間変化を示す．HC はソーク温度が低いほど濃度が高いこと が分かる。また、ソーク温度がー $20^{\circ} \mathrm{C}$ 以上の始動では始動直 後の HC の濃度ピークは確認できないが, $-25^{\circ} \mathrm{C}$ 以下だと鋭 い濃度ピークがある.これは図 2 に示すように, $-25^{\circ} \mathrm{C}$ 以下 の始動では始動に時間がかかるためクランキング時間が長 期化し、その間に噴射された燃料が燃焼することなく排出さ れ、HCの濃度ピークとなったと考えられる.

また, すべての温度条件で, エンジン始動後 260 秒以降で $\mathrm{HC}$ 濃度は一定值に落ち着いていることが分かる。クランキ ングから始動にかけて然焼しなかった未然然料がシリンダ 一壁面や排気管内に付着し、それら $\mathrm{HC}$ が排気温度の上昇に 伴い排出され、始動 260 秒ですべて排出されるため一定值と なるものと考えられる。

\section{3-2 低級炭化水素}

低級炭化水素であるメタン，エタン，エチレンおよびプロ ピレンを測定した．ただし，エタンとエチレンは分子量が近 くクロマトグラムのピークが重なり分離できないため, これ らの合計值をエタン・エチレンと表記する.

図 4 に各ソーク温度の後処理装置前におけるメタン, エタ ン・エチレンおよびプロピレン濃度の時間変化を示す.なお, 図ではクランキング開始を 0 秒としている. 全ての物質が始 動直後に高い值を示しており,クランキング中に燃料が熱分 解し低級炭化水素となったものが不完全燃焼により排出さ れたと考えられる. 各物質共にソーク温度が低いほど濃度が 高く，これは HCの排出傾向と同じである，その後，時間経 過と共に各成分の濃度は減少していく.

メタンは始動直後の濃度が他の成分と比べ高く, その後の 濃度低下も急激である. 特にソーク温度－ $30^{\circ} \mathrm{C}$ の始動直後お けるメタン濃度は顕著に高いことが確認できる.これは，図

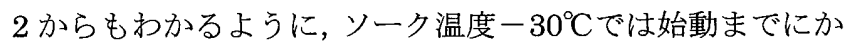
かる時間の長期化が顕著であり,また, その間に噴射された 燃料が非常に多いことが関係しているものと考えられる。

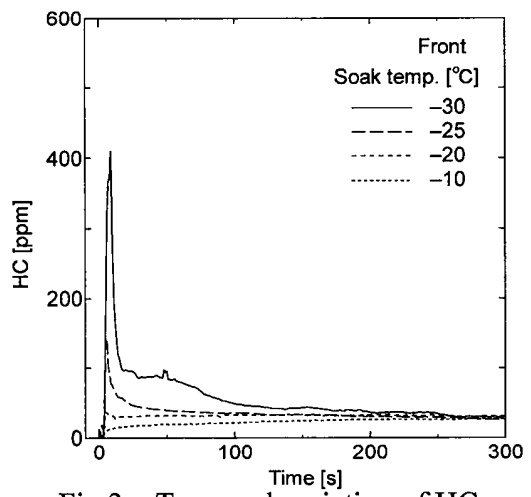

Fig.3 Temporal variation of $\mathrm{HC}$

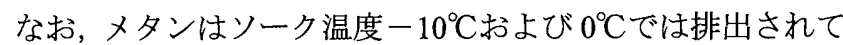
いない.

メタン以外のエタン・エチレンおよびプロピレンはメタン のような急激な濃度低下は見られず, ソーク温度－ $30^{\circ} \mathrm{C}$ を除く条件下での始動においては始動後約 50 秒で濃度は一 定值に落ち着いていることが確認できる.

\section{3-3 CO 濃度}

図 5 に各ソーク温度の後処理装置前における $\mathrm{CO}$ 濃度の時 間変化を示す. CO 濃度はクランキング開始から始動にかけ ての期間に高濃度で排出され，始動後は速やかに低濃度とな り，その後の排出は少ない．また，ソーク温度が低下するほ ど，ピーク濃度は高くなる。これは図 2 に示すように，ソー ク温度が低くなるほど始動までに時間がかかるため, 不完全 燃焼が多くなり，濃度が高くなったと考えられる。

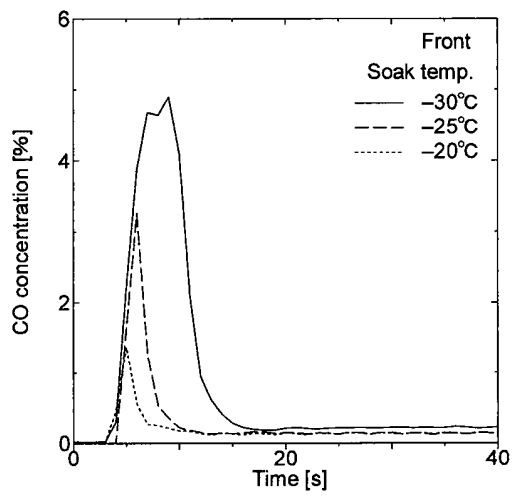

Fig.5 Temporal variation of $\mathrm{CO}$ concentration

\section{4. まとめ}

（1） HC 濃度はクランキング中に最も濃度が高くなり，その 後は減少する。.また, ソーク温度が低いほど, 高濃度と なる.

（2）メタン，エタン・エチレンおよびプロピレンは始動直後 に最も多く排出され，時間経過と共に減少していく．ま た，ソーク温度低下に伴い濃度は高くなる。

（3）CO 濃度はクランキング開始から始動直後に最も高く， その後は速やかに低濃度となる．また，ソーク温度が低 いほど多く排出される。

\section{参考文献}

1) Murari Mohon Roy, 常本秀幸, 石谷博美, 日本機械学 会論文集 (B 編)，65 巻 633 号, pp.1822-1828，(1999）

2) 小川英之，宮本登，KhandokerA.RAIHAN，滝本文人， 登坂茂, 藤原康博 : 過渡運転時におけるディーゼル末燃 炭化水素の排出および成分特性，日本機械学会論文集

(B 編)，Vol67，No.659，pp.1855-1860，（2001）
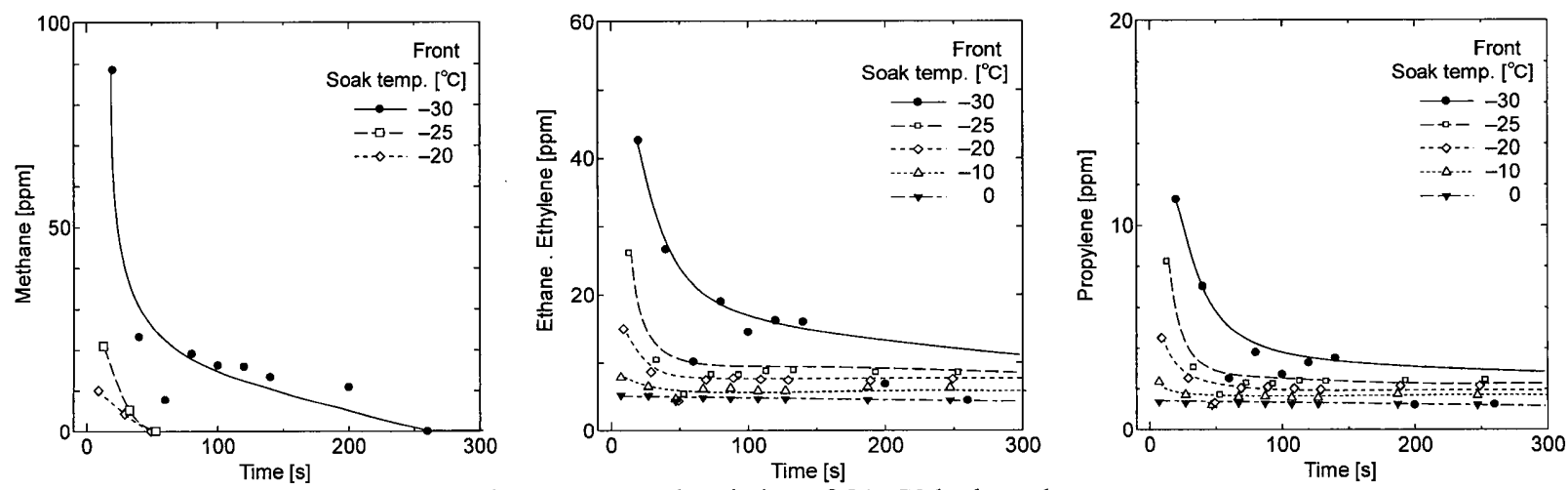

Fig.4 Temporal variation of $\mathrm{C} 1 \sim \mathrm{C} 3$ hydrocarbons 